\title{
Word of Mouth and Risk Perception toward the Decision on Using Go-Jek Services
}

\author{
Siska Lusia Putri ${ }^{1}$, Lasti Yossi Hastini ${ }^{2 *}$ \\ 1Dharma Andalas University, Padang, Indonesia, $₫$ siskalusiaputri@unidha.ac.id \\ 2Dharma Andalas University, Padang, Indonesia, $\bowtie$ lasti.yossi@gmail.com \\ *Corresponding Author
}

\begin{abstract}
The purpose of this study was to analyze the effect of WOM-Topics toward online transportation on using the sevice of Go-Jek in Padang City; to analyze the effect of RPSocial \& Time/Convenience toward online transportation on using the service of Go-Jek in Padang City and to analyze the effect of WOM-Topics and RP-Social \& Time/Convenience for taking decision on using the service of Go-Jek in Padang City. The data were collected from 384 respondents who have ever used Go-Jek for one year. The result of the study showed that (1) WOM-Topics partially has positive and significant impact on purchasing decision; (2) RP-Social \& Time/Convenience partially have negative and significant impact on purchasing decision; and (3) WOM-Topics and RP-Social \& Time/Convenience simultantly capable to explain the effect on purchasing decision. The value of adjusted $\mathrm{R}$ Square indicators was $47.4 \%$. For online transportation (Go-Jek), they should give more attention to their services for the consumers especially for the ordering which need longer time and longer route while occuring traffic jam and the convenience of consumers when they are on the trip. Moreover, the topics that consumers discussed about with the driver generally is about the promotions and the vouchers, it showed that the consumers fond of with the promotion given by the PT. Gojek Indonesia.
\end{abstract}

Keywords: word of mouth, risk perception, transportation, purchasing decision, Go-Jek

\section{Introduction}

The development in number of vehicles based on the the types of vehicle in Padang city have increased from 395.632 units in 2016 to 398.401 units in 2017 (BPS, 2018). This industrial growth occured because of the existence of online transportation in Padang city around in the middle of 2017. According to the research conducted by Susanto, et al. (2011) stated that the reason why the development of vehicles were high was the citizen was easy to get credit in purchasing motorcycle.

Around 2011, PT. Gojek Indonesia (Go-Jek) established an online-transportation with the purpose to give an easiness in mobiling and ordering food. Go-Jek an Indonesian work is founded by Nadiem Makarim. There are varrious services such as Go-Ride and Go-Jek as mobiling services, orderingdelivering service (Go-Food), and shopping (Go-Shop).

Go-Jek has existed in Padang city since in the middle 2017. The Padang citizen welcomed this services very well and even Go-Jek has became the main part of their daily need (nasional.republika.co.id). They often discuss about various promotion such as vouchers of Go-Ride or Go-Car. The voucher can raise $50 \%-70 \%$ off even there is a free bill voucher which can be set-out in random time. Sometimes many consumers do not realize about it. They often get the information from their friends or their family (harianhaluan.com).

Word of Mouth (WOM) is one way of promotion that triger a consumer to make a discussion about the product or the service, promote the product or service and recommend the product or the service and sell the product's or service's label used by others pre-customers. WOM will triger the pre-customers to buy the product or the service that have been heard from friends, family, even the new person when they buy the product or the service (Sumardy, 2011). When a pre-customers know the information about the product or the service from mouth to mouth, so they will consider it first. The positive and negative side will be evaluated before taking a decision to buy the product or the service or not. Putri, et al. (2013) adds that topic is there is an ordered or something that makes them 
talk about the product or service, is likely other services that given because our product has its own quality.

Sumarwan (2011) stated that the decision to buy a product or a service with certain label will be started by this following steps: (a) recognition of needs, (b) information search, and (c) alternative evaluation. The factors which effected the information search cover risk perception factor. Consumer's characteristics factor (word of mouth), and situation factor. Alternative evaluation is a process evaluate the selection of product and brand and choose what consumer want. On the alternative evaluation process, the consumners compared various choices which can solve the problem at hand.

Moreover the process after the purchasing the product or service, consumers will do an assessment to the product which has been used. Sumarwan (2011) stated that the result of this evaluation process after purchasing was the consumers felt satisfied or not on the product or brand that had been consumed. In this way, WOM wil be positive or negative. It will be positive if the consumers satisfied on the product or service, then it will continue positively. Otherwise, it will negative if the consumers felt dissapointed or unsatisfied and continued negatively. This is the important role of WOM as a strategic tool of promotion for a company in influencing the consumers in making a buying decision.

Simamora and Azis (2016) conducted a research about WOM in WOM-Talkers, WOM-Tools, WOM-Talking Part and WOM-Tracking toward the buying of Go-Jek in Bandung. Bandung as on of the target market of Go-Jek that has been operated in April 2015. WOM about Go-Jek as an onlinetransportation in Bandung quite enthusiastic. Ridwan Kamil as the mayor of Bandung city, supported the existence of Go-Jek in Bandung. How significant the development of online-transportation in Bandung, become the consideration of the researcher to conduct a further research, how promotion strategy that has been done by Go-Jek in Bandung.

Commonly, consumers tend to rely on private institution in deciding whether something has a risk or not, that may be influenced by previous personal experience, involvement rate, or ordering price (Sumarwan, 2011). Perceived risk has moderate effect for consumers because they tend to avoid a mistake (risk avoidance). Sumarwan (2011) also add more perception the consumers have toward the product that they will buy, more they will find the information about the product. Then Putri, et al. (2013) explained that Risk Perception-Social (RP-Social \& Time/Convenience Risk) is a risk that has connection with the product which have less-competing value than the competitor's product and the failure of a product that has been used as a chance to find another satisfied product.

A research about perception risk generally has relationship with a risk in purchasing product by online, adopting of new product and ordering an airline ticket by internet (Putri, et al., 2013). The research about perception risk toward the decision on using the service is rarely found to be analyzed, such in land transportation (angkot, taxi, ojek), water transportation (ship) and air transportation (airplane).

The research of Kunze and Mai (2007); Pi and Sangruang (2011); and Putri, et al. (2013) has the same result that time risk and performance risk affect in consumer's purchasing decision. Kunze and Mai (2007) about the adoption music downloding service showed that performance risk and time risk influence the respondents in adoption music downloading service. Social risk, psychological risk, physical risk and financial risk are not influence the respondents in adoption music downloading service. Then, Pi and Sangruang (2011) about purchasing perception risk by online showed that time convenience risk, physical risk, performance risk and social risk are the most influencing factor when we do a purchasing by online. Psychological risk and financial risk are not influence the respondents in purchasing by online. Then Putri, et al. (2013) about perception risk use Garuda Indonesia showed that time risk and performance risk influence the respondents in using the service of Garuda Indonesia.

The researches by Cunningham et al. (2005) and Hirunyawipada and Paswan (2006) have the same finding that social risk and physical risk affect in consumer's purchasing decision. Cunningham et al.(2005) conducted a reseach about booking of an airline ticket by internet and traditional. The 
finding showed that performance risk, physical risk, social risk and financial risk have a risk in a process of consumer's buying. Psychological risk and time risk do not have an effect toward the ticket ordering process by internet. Meanwhile, Hirunyawipada and Paswan (2006) about the adoption of a new product showed that social risk and physical risk affect the respondents in adopting a new product.

That is why the researchers eager to conduct a study about Word Of Mouth (WOM); WOM-topics and perception risk; RP-Social \& Time/Convenience. The purpose of this study is to analyze RP-Social \& Time/Convenience toward the making decision in using the Go-Jek services in Padang city.

\section{Methods}

\section{Types and Sources of Data}

Types of data that being used in this study is primer data dan secondary data. Primer data was gotten by discussing and interviewing directly conducted by questionnaire. Secondary data was gotten from many relevant libraries resourses.

\section{Techniques of Collecting Data}

In collecting data, this study was conducted by directly interviewed the respondents by using questionaire tools. The criteria of the prospective respondents as a sample in this survey was the consumers of online-transportation Go-jek. This survey was done at least once in average age over 17year-old. Thus, the definition of the operational for each variables used in this study are;

1. Independent variable $(X)$

According to Sarwono (2012), independent variable is one of variable which is measured, manipulated or selected by the researchers to determine the relationship with an indication being observed. The independent variable in this study is WOM-Topics $\left(\mathrm{X}_{1}\right)$ and RP-Social \& Time/Convenience $\left(X_{2}\right)$.

2. Dependent Variable ( $\mathrm{Y})$

Dependent variable is a variable which gave reaction or respond, if it is connected with independent variable. Dependent variable in this study is the purchasing decision $(\mathrm{Y})$.

The complete data is showed in Table 1.

Table 1 Definition of Operational Variable

\begin{tabular}{|c|c|c|c|c|}
\hline Variable & Sub-Variable & $\begin{array}{c}\text { Definition } \\
\text { Operational }\end{array}$ & Indicator & Symbol \\
\hline $\begin{array}{l}\text { WOM / } \\
\text { Word of } \\
\text { Mouth }\end{array}$ & Topics $\left(\mathrm{X}_{1}\right)$ & $\begin{array}{l}\text { Topics is the } \\
\text { message or } \\
\text { something that } \\
\text { makes them discuss } \\
\text { about the product or } \\
\text { service, for example } \\
\text { our service, it } \\
\text { caused of the quality } \\
\text { of our service. } \\
\text { (Sernovitz, 2012) }\end{array}$ & $\begin{array}{l}\text { 1. The discussion of the } \\
\text { price } \\
\text { 2. The discussion of the } \\
\text { drive's service } \\
\text { 3. The discussion of the } \\
\text { vehicle } \\
\text { (source: Antonetti P dan } \\
\text { Maklan S, 2018; Raymond } \\
\text { R, 2015; and Simamora \& } \\
\text { Azis, 2016) }\end{array}$ & $\begin{array}{l}X_{1.2} \\
X_{1.3}\end{array}$ \\
\hline $\begin{array}{l}\text { RP / Risk } \\
\text { Perception }\end{array}$ & $\begin{array}{c}\text { Social Risk \& } \\
\text { Time/ } \\
\text { Convenience } \\
\text { Risk } \\
\left(\mathrm{X}_{2}\right)\end{array}$ & $\begin{array}{l}\text { Social Risk \& Time/ } \\
\text { Convenience Risk is } \\
\text { a product which is } \\
\text { not better than its } \\
\text { competitor anf the } \\
\text { failure of a product } \\
\text { that has been used is } \\
\text { the chance to find }\end{array}$ & $\begin{array}{l}\text { 1. Go-Jek is a prestige for } \\
\text { its consumers } \\
\text { 2. They choose Go-Jek } \\
\text { because of the social } \\
\text { intercourse } \\
\text { 3. Effective in time } \\
\text { because of traffic jam } \\
\text { 4. Incomfortable while }\end{array}$ & $\begin{array}{l}X_{2.1} \\
X_{2.2}\end{array}$ \\
\hline
\end{tabular}




\begin{tabular}{|c|c|c|c|}
\hline Table Cont... & $\begin{array}{l}\text { another one that } \\
\text { more satisfied. } \\
\text { (Kotler and Keller, } \\
2009 \text { ) }\end{array}$ & $\begin{array}{l}\text { driving } \\
\text { (source: Cunningham et } \\
\text { al. (2005); Hirunyawipada } \\
\text { and Paswan (2006); and } \\
\text { Putri, et al. (2013)) }\end{array}$ & \\
\hline $\begin{array}{l}\text { Purchasing } \\
\text { decision }(Y)\end{array}$ & $\begin{array}{l}\text { Purchasing decision } \\
\text { is an the last } \\
\text { personal consumers } \\
\text { buying decision and } \\
\text { household who buy } \\
\text { a product and } \\
\text { service for personal } \\
\text { consuming } \\
\text { (Kotler and Keller, } \\
\text { 2009) }\end{array}$ & $\begin{array}{l}\text { 1. Re-buying proclivity } \\
\text { 2. Recommendation } \\
\text { (source: Antonetti P and } \\
\text { Maklan S (2018); } \\
\text { Raymond R (2015); } \\
\text { Cunningham et al. (2005); } \\
\text { Hirunyawipada and } \\
\text { Paswan (2006); and Putri, } \\
\text { et al. (2013)) }\end{array}$ & $\begin{array}{l}Y_{1.1} \\
Y_{1.2}\end{array}$ \\
\hline
\end{tabular}

\section{Method Tabulation and Analyzing Data}

This study analyze the effect of WOM-topics and RP-Social \& Time/Convenience the consumers who uses the service in taking decision. Next in Picture 1 showed the conceptual framework.

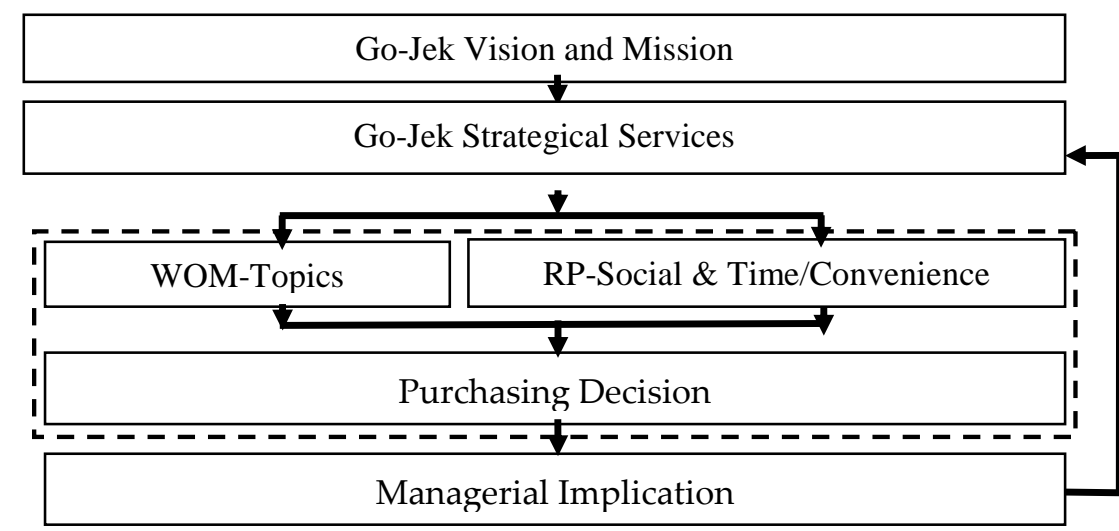

Information:

ロㅡ = Research Scope

\section{Results and Discussion}

Figure 1 Conseptual Framework

\section{Respondents Characteristic}

Demography data included gender, age, job, the lastest education and fee for transportation. Complete data will be showed in the following Table 2.

Table 2 Distribution respondents based on their demography

\begin{tabular}{rrrrr}
\hline No. & Demography & & $\begin{array}{c}\text { Respondents } \\
\text { (person) }\end{array}$ & Percentage (\%) \\
\hline 1 & Gender & & & \\
\hline & & Male & 282 & 73.4 \\
\hline & & Female & 102 & 26.6 \\
\hline & & Total & 384 & 100 \\
\hline 2 & Age & & & 80.7
\end{tabular}


Table Cont...

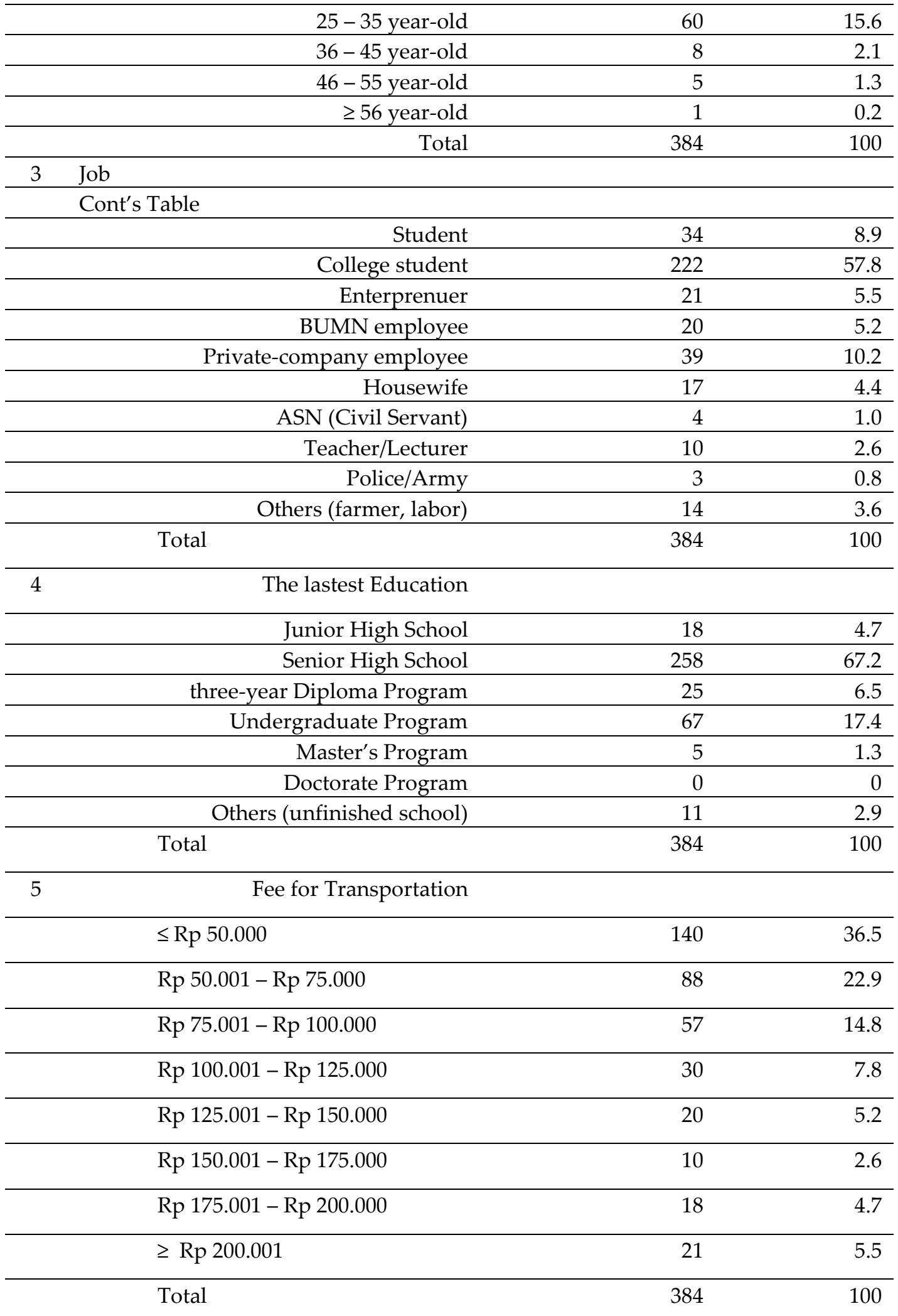

\section{Descriptive Analysis}

To find out how respondent's perception toward topics, social \& time/convenience and purchasing decision can be explained through descriptive analysis. In this study descriptive analysis as follows 
Table 3 Descriptive Analysis

\begin{tabular}{|c|c|c|c|}
\hline Statement & Mean & TCR (\%) & Explanation \\
\hline \multicolumn{4}{|l|}{ TOPICS } \\
\hline $\begin{array}{l}\text { I choose online transportation (GO-Jek) because there is } \\
\text { a discussion about the cost (e.g. promition and voucher) }\end{array}$ & 3.07 & 79.82 & Good \\
\hline $\begin{array}{l}\text { I choose online transportation (GO-Jek) because there is } \\
\text { a discussion about driver's performances and services. }\end{array}$ & 2.91 & 75.81 & Good \\
\hline $\begin{array}{l}\text { I choose online transportation (GO-Jek) because there is } \\
\text { a discussion about driver's performances and services. }\end{array}$ & 2.71 & 70.59 & Good \\
\hline \multicolumn{4}{|c|}{ SOCIAL \& TIME/CONVENIENCE } \\
\hline $\begin{array}{l}\text { I still choose online transportation (Go-Jek) because of } \\
\text { its pretigious. }\end{array}$ & 2.67 & 69.51 & Good \\
\hline $\begin{array}{l}\text { I still choose online transportation (Go-Jek) because of } \\
\text { social intercouse (e.g. family, friends, and colleague) }\end{array}$ & 2.56 & 66.59 & Good \\
\hline $\begin{array}{l}\text { I still choose online transportation (Go-Jek) although } \\
\text { takes more time. }\end{array}$ & 2.22 & 57.71 & Enough \\
\hline $\begin{array}{l}\text { I still choose online transportation (Go-Jek) although it } \\
\text { less convenience while riding }\end{array}$ & 1.95 & 50.79 & Enough \\
\hline \multicolumn{4}{|l|}{ PURCHASING DECISION } \\
\hline I still use online transportation (Go-Jek) & 3.24 & 84.43 & Very Good \\
\hline $\begin{array}{l}\text { I will recommend online transpotation (Go-Jek) to } \\
\text { others }\end{array}$ & 3.15 & 81.99 & Very Good \\
\hline
\end{tabular}

In this study was obtained that topics variable from three statements have answered enough, with the highest mark in the statement "I still choose online transportation (Go-Jek) although the performance of the drivers are not tangible" with the respondents level reach $60.36 \%$. Meanwhile the statement with the lowest mark is the statement "I still choose online transportation (Go-Jek) although the driver drove his car unsafety" with the respondents level $42.28 \%$.

In Social \& Time/Convenience variable from three statements answered enough, with the highest mark is the statement "I still choose online transportation (Go-Jek) although the ride under the standard" with the respondents level $49.5 \%$. Meanwhile the statement with the lowest mark is "I still choose online transportation (Go-Jek) although it is not safe" with the respondents level $42.65 \%$.

In Purchasing Decision variable from two statements answered very good. The highest mark with the statement "I will still use online transportation (Go-Jek) again" with the respondents level $84.43 \%$. Meanwhile the statements with the lowest mark is "I will recommend online transportation (Go-Jek) to the others" with the respondents level $81.99 \%$.

\section{Multiple Linear Regression Analysis}

Regression analysis was used to know how much the effect of independent variable toward dependent variable. The following illustrates the multiple linear regression analysis.

Table 4 Multiple Linear Regression Analysis

\begin{tabular}{|c|c|c|c|c|c|c|c|}
\hline \multirow[t]{2}{*}{ Model } & \multicolumn{2}{|c|}{$\begin{array}{l}\text { Unstandardized } \\
\text { Coefficients }\end{array}$} & \multirow{2}{*}{$\begin{array}{c}\begin{array}{c}\text { Standardized } \\
\text { Coefficients }\end{array} \\
\text { Beta }\end{array}$} & \multirow[t]{2}{*}{$\mathrm{T}$} & \multirow[t]{2}{*}{ Sig. } & \multicolumn{2}{|c|}{$\begin{array}{c}\text { Collinearity } \\
\text { Statistics }\end{array}$} \\
\hline & $\mathrm{B}$ & Std Eror & & & & $\begin{array}{c}\text { Toleranc } \\
\mathrm{e}\end{array}$ & VIF \\
\hline Constant & 2.419 & .434 & & 5.576 & .000 & & \\
\hline Topics & .171 & .033 & .280 & 5.168 & .000 & .467 & 2.139 \\
\hline $\begin{array}{l}\text { Social E } \\
\text { Time/Convenience }\end{array}$ & -.052 & .025 & -.115 & -2.076 & .039 & .449 & 2.227 \\
\hline
\end{tabular}


Based on Table 4 was obtained multiple linear regression analysis :

$\mathrm{Y}=\mathbf{a}+\mathbf{b}_{1} \mathbf{X}_{1}+\mathbf{b}_{2} \mathbf{X}_{2}+\mathbf{e}$

$Y=2.419+0.171 X_{1}-0.052 X_{2}+e$

From this equation, it can be explained that;

1. Positive constant is 2.419. This is showed that if there is no topics and social \& time/convenience variable, so the decision of using Go-Jek sevice has constant value about 2.419.

2. Coefficient value Topics $\left(X_{1}\right)$ is positive 0.171 and its significancy value $0.000<0.05$. This is showed that if topics increase as much as at one so the decision the using of Go-Jek (Y) will increase as much as 0.171 or $17.1 \%$ by asumption the social \& time/convenience is stagnant.

3. Coefficient value Social \& Time/Convenience $\left(X_{2}\right)$ is negative 0.052 and its significancy value 0.039 $<0.05$. This is showed that if Social \& Time/Convenience increase as much as at one so the decision the using of Go-Jek (Y) will decrease as much as 0.052 or $5.2 \%$ by asumption the topics is stagnant.

\section{Classic Assumption Test \\ Normality Test}

Normality test on regression mode was used to test whether residual value that showed by the regression was distributed normally or not. A good regression mode is an regression which has the residual value distributed normally. In this study, normality test is explained in the following diagram.

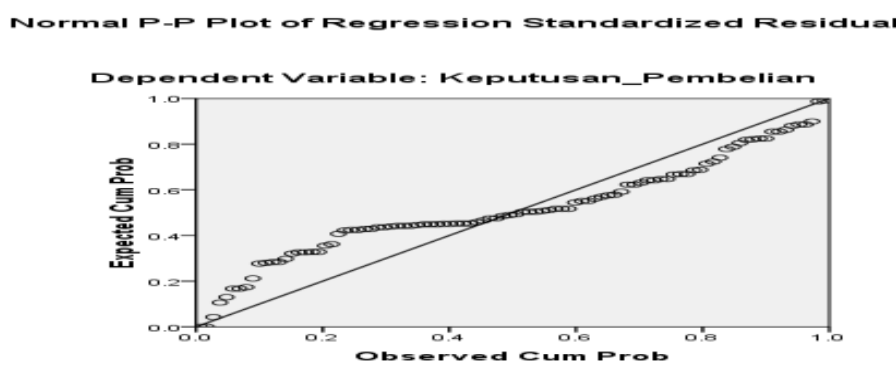

Figure 2 Normality Test

Based on analysis above, it can be seen that the data are spreaded around the diagram and followed the regression mode. So it can be concluded that the data processed are distributed normally therefore the normality test completed.

\section{Multicolinearity test}

According to Ghozali (2011), multicolinearity test intended to test whether regression models found a correlation between independent variables. A good regression model should not be a correlation between independent variables. If there is correlation between that regression model, there is multicolinearity problem in that regression. To see there is a multicolinearity in regression model or not can be seen from tolerance value and variance inflation (VIF). If tolerance value $\geq 0.1$ and VIF value $\leq 10$, so there is no multicolinearity, otherwise, if tolerance value $\leq 0.1$ and VIF $\geq 10$, so there is multicolinearity inter-independent variable in regression mode. For the analysis by SPSS we see the output on table "Coefficients" in the following table.

Table 5 Multicolinearity Test

\begin{tabular}{lccccccc}
\hline \multicolumn{1}{c}{ Model } & \multicolumn{2}{c}{$\begin{array}{c}\text { Unstandardized } \\
\text { Coefficients }\end{array}$} & $\begin{array}{c}\text { Standardized } \\
\text { Coefficients }\end{array}$ & T & & Sig. & \multicolumn{2}{c}{$\begin{array}{c}\text { Collinearity } \\
\text { Statistics }\end{array}$} \\
\cline { 2 - 4 } \cline { 7 - 9 } & $\mathbf{B}$ & Std Eror & Beta & & & Tolerance & VIF \\
\hline \multicolumn{1}{c}{ Constant } & 2.419 & .434 & & 5.576 & .000 & & \\
\hline Topics & .171 & .033 & .280 & 5.168 & .000 & .467 & 2.139 \\
\hline Social \& & -.052 & .025 & -.115 & -2.076 & .039 & .449 & 2.227 \\
Time/Convenience & & & & & & & \\
\hline
\end{tabular}


From the output data was obtained that the whole VIF value $<10$. It means that there is no multicolinearity. And it can be concluded that classical assumption test fulfilled.

\section{Heterocedastisity Test}

According to Ghozali (2011), heterocedastisity test intended to know whether in regression model variance from residual inequality one observation to another observation. If the variance from residual from one to other one is stable, it is called homocedastisity. Otherwise, if the variance from residual from one to other one is diffrence is called heterocedastisity. To detect and analyze the data, can be seen in the "Scatterplot" image in the data output as shown below.

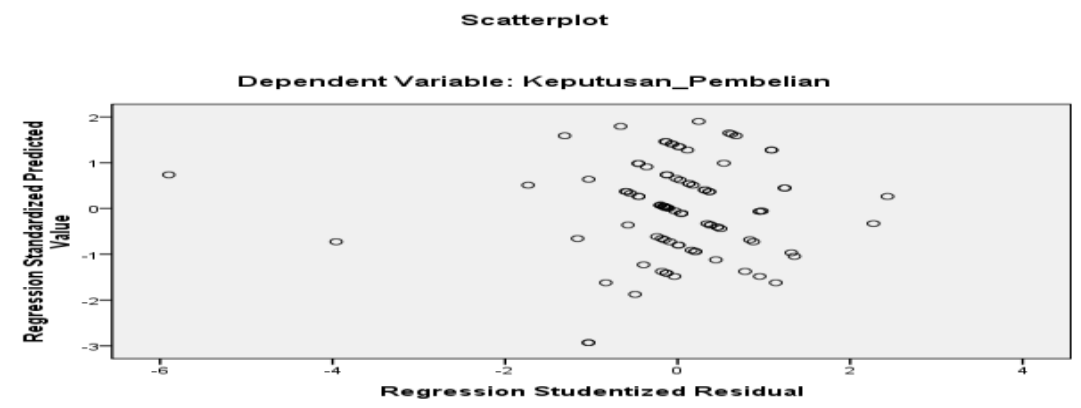

Figure 3 Heterocedastisity Test

From the picture above it can be seen that there is no heteroscedasticity because there are no clear patterns and the points spread above and below the number 0 on the $\mathrm{Y}$ axis. So that the classic assumption test can be said to be fulfilled.

\section{Hypotheses Test}

\section{Partial Test (t Test)}

According to Sugiyono (2014), t Test is used to know the contribution of each free variable partially toward dependent variable. Using each regression variable, which independent variable has significant influence or not toward dependent variable. This is the $t$ Test in this study that can be seen in the following Table.

Table $6 \mathrm{t}$ Test

\begin{tabular}{|c|c|c|c|c|c|c|c|}
\hline \multirow[t]{2}{*}{ Model } & \multicolumn{2}{|c|}{$\begin{array}{l}\text { Unstandardized } \\
\text { Coefficients }\end{array}$} & \multirow{2}{*}{$\begin{array}{c}\begin{array}{c}\text { Standardized } \\
\text { Coefficients }\end{array} \\
\text { Beta }\end{array}$} & \multirow[t]{2}{*}{$t$} & \multirow[t]{2}{*}{ Sig. } & \multicolumn{2}{|c|}{$\begin{array}{l}\text { Collinearity } \\
\text { Statistics }\end{array}$} \\
\hline & B & Std Eror & & & & Tolerance & VIF \\
\hline Constant & 2.419 & .434 & & 5.576 & .000 & & \\
\hline Topics & .171 & .033 & .280 & 5.168 & .000 & .467 & 2.139 \\
\hline $\begin{array}{l}\text { Social \& } \\
\text { Time/Convenience }\end{array}$ & -.052 & .025 & -.115 & -2.076 & .039 & .449 & 2.227 \\
\hline
\end{tabular}

Based on Table 6, t Test can be interpreted as follow:

1. The effect of WOM-Topics toward the purchasing decision from the result of the hyphotheses test WOM-Topics $\left(\mathrm{X}_{1}\right)$, partially showed $t$ has value as 5.168 bigger than $t$ table 1.966 with significant 0.000 less than 0.05 . it means that hyphotheses in this study rejects Ho and accepts Ha. So, it can be concluded that hyphotheses $\mathrm{H}_{1}$ "WOM-Topics $\left(\mathrm{X}_{1}\right)$ has significant impact on purchasing decision".

2. The effect of RP-Social \& Time/Convenience toward the purchasing decision, the result of the hyphotheses RP-Social \& Time/Convenience $\left(\mathrm{X}_{2}\right)$, partially showed $\mathrm{t}$ has value as -2.076 less than $\mathrm{t}$ table which has 1.966 with significant value 0.0039 less than 0.05 . it means that hyphotheses in 
this study rejects $\mathrm{Ho}$ and accepts $\mathrm{Ha}$. So, it can be concluded that hyphotheses $\mathrm{H}_{2}$ "RP-Social \& Time/Convenience $\left(\mathrm{X}_{2}\right)$ has negative impact and significant on purchasing decision".

\section{Simultant Test (F Test)}

Sugiyono (2014) stated that F test is used to know whether independent coefficient variable simultantly has real effect or not toward dependent variable. This is the F Test in this study that can be seen in the following Table.

Table 7 F Test

\begin{tabular}{lrrrrr}
\hline \multicolumn{1}{c}{ Model } & Sum of Squares & \multicolumn{1}{c}{ Df } & Mean Squares & \multicolumn{1}{c}{ F. } & \multicolumn{1}{c}{ Sig. } \\
\hline Regression & 337.375 & 9 & 37.486 & 39.378 & .000 \\
\hline Residual & 356.031 & 374 & .952 & & \\
\hline Total & 693.406 & 383 & & & \\
\hline
\end{tabular}

The result of the hyphotheses WOM-Topics and RP-Social \& Time/Conveinence toward the purchasing decision showed $\mathrm{F}$ value as much as 39.378 with significant level 0.000 . This significant level less than 0.05. It means that hyphotheses in this study rejects Ho and accept Ha. Therefore it means that hyphotheses "WOM-Topics and RP-Social \& Time/Conveinence have significant impact on purchasing decision".

\section{Determinant Coefficient $\left(\mathbf{R}^{2}\right)$}

According to Ghozali (2011), determinant coefficient $\left(R^{2}\right)$ mainly to measure how far the mode capability in explaining various dependent variable. Determinant coefficient value is between zero (0) and one (1). The small value of $R^{2}$ means that the capability of independent variables in explaining the dependent variable is very limited. The value which near one (1) means that the independent variable gives almost all the information needed to predict the dependent variables. In this study determinant coefficient Test of WOM-Topics and RP-Social \& Time/Conveinence can be seen on this following table.

Table 8 Deteminant Coefficient Test $\left(\mathbf{R}^{2}\right)$

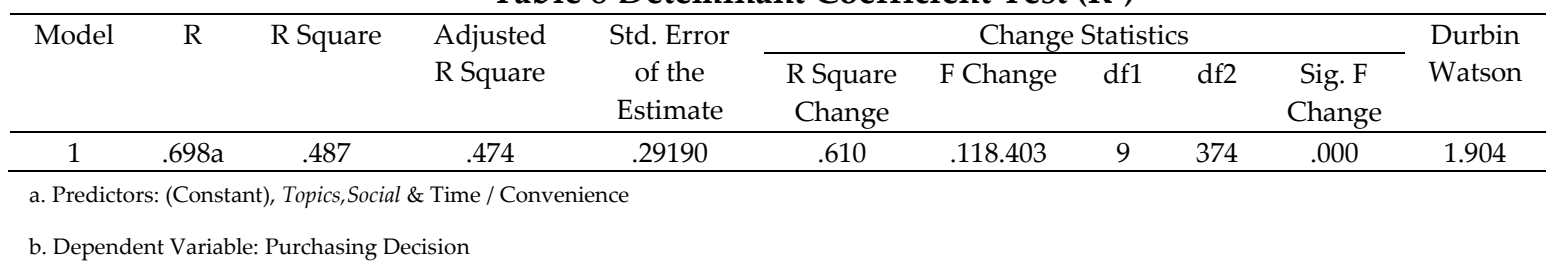

From the table above showed that there is significant impact of WOM-Topics and RP-Social \& Time/Conveinence toward the purchasing decision as much as 0.474 or $47.4 \%$, meanwhile the rest as much as $52.6 \%$ is effected by othe variable that cannot be analyzed in this study.

\section{Discusssion}

From the result of the study that has been analyzed by using SPSS, it can be explained that the using of online transportation (Go-Jek) as below;

The effect of WOM-Topics toward the purchasing decision based on hyphotheses test.

The WOM-Topics showed that $t$ value as much as 5.168 more than $t$ table as much as 1.966 and the significant level 0.0000 less than 0.05 . So, it can be concluded that "WOM-Topics $\left(\mathrm{X}_{1}\right)$ has positive and significant impact toward the purchasing decision." It means that the consumers who has used the product or the service tended to choose or decide a product or service depends on the topic of conversation with the driver. So, it will bring the positive effect on purchasing decision. This result relevant with the study conducted by Simamora \& Azis (2016). However, it has contrary with the study conducted by Antonetti \& Maklan (2018) and Raymond (2015). 
The effect of RP-Social \& Time/Convenience toward the purchasing decision based on the result of hyphotheses test.

$\mathrm{RP}$-Social \& Time/Convenience $\left(\mathrm{X}_{2}\right)$ showd that $\mathrm{t}$ value as much as -2.076 less than $\mathrm{t}$ table as much as 1.966 and the significant level 0.039 less than 0.05 . So, it can be concluded that "RP-Social \& Time/Convenience $\left(\mathrm{X}_{2}\right)$ has negative impact and significant toward the purchasing decision". It means that the consumers who has used the product or service tended to choose or decided, a product or service depends on social factors and the ease of time, so it will bring the negative impact on purchasing decision. This result is similar with the result conducted by Cunningham et al. (2005); Hirunyawipada and Paswan (2006); Kunze \& Mai (2007); Pi \& Sangruang (2011); and Putri et al. (2013) in which the result of regression coefficient is positive.

The whole effect of Word of Mouth (WOM) and Risk Perception (RP) toward the purchasing decision.

The result of F test (simultantly) WOM-Topics and RP-Social \& Time/Convenience toward the purchasing decision is as much as 0.474 or $47.4 \%$. This is showed that WOM-Topics and RP-Social \& Time/Convenience capable to explain its impact toward the purchasing decision as much as $47.4 \%$, while the rest $52.6 \%$ is affected by others factor.

\section{Conclusion}

The result of the study showed that on the online transpotation (Go-Jek); (1) WOM-Topics $\left(\mathrm{X}_{1}\right)$ partially has positive effect and significant toward the purchasing decision; (2) RP-Social \& Time/Convenience $\left(\mathrm{X}_{2}\right)$ variable partially has negative and significant toward the purchasing decision; and (3) WOM-Topic and RP-Social \& Time/Convenience variable simultantly capable to explain its impact toward the purchasing decision as much as $47.4 \%$.

For online transportation (Go-Jek), it gives more attention to their services fo the consumers especially for the ordering which need longer time and longer route while occuring traffic jam. Then, the convenience of consumers when they are on the riding trip. Moreover, the topics that consumers discussed about with the driver generally is about the promotions and the vouchers. This is showed that the consumers fond of with the promotion given by the PT. Gojek Indonesia.

\section{References}

Antonetti P dan Maklan S. (2018). Identity Bias in Negative Word of Mouth Following Irresponsible Corporate Behavior: A Research Model and Moderating Effects. Journal of Business Ethics.149: 1005-1023.

Badan Pusat Statistik. (2018). Padang City in 2018 Figures. Accessed on Februari 27th 2019 at 11.13.

Cunningham LF, James HG, Michael DH, Clifford EY. (2005). Perceived Risk and the Consumer Buying Process: Internet Airline Reservations. Service Management 16:357-373.

Ghozali, I. (2011). Multivariate Analysis Application with the 19 IBM SPSS Program. 5th Ed. Semarang: Diponegoro University.

Harianhaluan.com [accessed on Agustus 20 th (2018) at 10.15].

Hirunyawipada T, Paswan AK. (2006). Consumer Innovativeness \& Perceived Risk a: Implications for High Technology Product Adoption. Marketing and Logistic 23(4):182-198.

Kotler P, Kevin LK. (2009). Marketing Management. 13th Ed.Jilid I. Jakarta: Erlangga. Translation from: Bob Sabran.

Kunze O, Mai L. (2007). Consumer Adoption of Online Music Services: The Influence of Perceived Risk and Risk-relief Strategies. Retail and Distribution Management 35(11):862-877.

Nasional.republika.co.id [accessed on Agustus 20 th 2018 at 10.25].

Pi SM, Sangruang J. (2011). The Perceived Risks of Online Shopping in Taiwan.Social Behavior and Personality 39(2):275. 
Putri, SL, Lilik NY, Febriantina D. (2012). Analysis of Consumer Attitudes Towards Airlines and the Influence of Risk Perception on Decisions Using Indonesian Garuda Services [thesis]. Bogor:Sekolah Program Pascasarjana, InstitutPertanian Bogor.

Putri, SL, Lilik NY, Febriantina D. (2013). Analysis of Consumer Attitudes Towards Airlines and the Influence of Risk Perception on Decisions Using Indonesian Garuda Services. Ekonomi and Bisnis Dharma Andalas. Vol. 14 No.1 49-62.

Raymond R. (2015). When Word-of-Mouth Goes Online: Evaluating The Characteristics and Effects of Ewom Communication. International Journal of Arts $\mathcal{E}$ Sciences.499- 508.

Sarwono J. (2012). Thesis Research Methods A Quantitative Approach Using the SPSS Prosedure. 1st Ed.Jakarta:Elex Media Komputindo.

Sernovitz, A. (2012). Word of Mouth Marketing: How Smart Companies Get People Talking. Greenleaf Book Group Press.

Simamora A, Azis E. (2016). The Influence of Word of Mouth on Purchasing Decisions on Go-Jek in Bandung City. e-Prosiding of Management: Vol.3, No.1, April 2016, 151-156.

Sugiyono. (2014). Business Research Method.Bandung:Alfabeta.

Sumary. (2011). The Power of Word of Mouth Marketing. Jakarta: Gramedia.

Sumarwan U, Ahmad J, Asep M, Bagio NK, Ponti KM, Wahyu N. 2011. Marketing and Consumer Research (Research and Study Guidelines: Satisfactions, Buying Behavior, Lifestyle, Loyalty, and Risk Perception). Bogor: IPB Press.

Susantono B, Santoso W, dan Budiyono A. (2011). Vehicle Ownership and Travel Patterns in the Jabodetabek Area. Transportation Journal. Vol 11 No 3, Desember 2011, page : 153-162. 